Prepared in cooperation with the Puerto Rico Aqueduct and Sewer Authority

\title{
Sedimentation Survey of Lago Cerrillos, Ponce, Puerto Rico, April-May 2008
}

Scientific Investigations Report 2011-5057 


\section{Cover Photograph}

Aerial photograph of the Lago Cerrillos Dam, Ponce, Puerto Rico. Photograph courtesy of the Puerto Rico Electric Power Authority, taken on May 9, 2006. 


\section{Sedimentation Survey of Lago Cerrillos, Ponce, Puerto Rico, April-May 2008}

By Luis R. Soler-López

Prepared in cooperation with the Puerto Rico Aqueduct and Sewer Authority

Scientific Investigations Report 2011-5057 


\title{
U.S. Department of the Interior \\ KEN SALAZAR, Secretary \\ U.S. Geological Survey \\ Marcia K. McNutt, Director
}

\section{U.S. Geological Survey, Reston, Virginia: 2011}

Revised and reprinted: 2011

\author{
For more information on the USGS — the Federal source for science about the Earth, its natural and living \\ resources, natural hazards, and the environment, visit http://www.usgs.gov or call 1-888-ASK-USGS. \\ For an overview of USGS information products, including maps, imagery, and publications, \\ visit http://www.usgs.gov/pubprod \\ To order this and other USGS information products, visit http://store.usgs.gov
}

Any use of trade, product, or firm names is for descriptive purposes only and does not imply endorsement by the U.S. Government.

Although this report is in the public domain, permission must be secured from the individual copyright owners to reproduce any copyrighted materials contained within this report.

Suggested citation:

Soler-Lopez, L.R., 2011, Sedimentation survey of Lago Cerrillos, Ponce, Puerto Rico, April-May 2008: U.S. Geological Survey Scientific Investigations Report 2011-5057. 


\section{Contents}

Abstract
Introduction
Description of Cerrillos Dam and Reservoir, and General Basin Characteristics
Method of Survey
$\quad$ Field Techniques
Sediment Pccessing
Lago Cerrillos Sediment Trapping Efficiency and Water Renewal Rate
Lago Cerrillos Drainage Area Sediment Yield and Reservoir Life Expectancy
Summary and Conclusions
References Cited

\section{Plate}

in pocket

1. Lago Cerrillos, Puerto Rico, Bathymetry, 2008. 


\section{Figures}

1-5. Maps showing-

1. Location of Lago Cerrillos in the south coast of Puerto Rico, within the Río Guayanilla and the Río Coamo basins.

2. Planned survey lines for the April-May 2008, bathymetric survey of Lago Cerrillos,

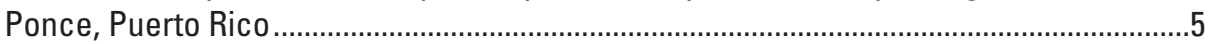

3. Actual track lines where bathymetric data were collected in Lago Cerrillos, Ponce, Puerto Rico, April-May 2008 .......................................................................................

4. Triangulated irregular network (TIN) surface model of Lago Cerrillos, Ponce, Puerto Rico, 2008

5. Reference longitudinal distance along the thalweg of Lago Cerrillos, Ponce, Puerto Rico, 2008

$6-9$. Graphs showing-

6. Relation between reservoir pool elevation and water-storage capacity of Lago Cerrillos, Ponce, Puerto Rico, for 1991 and 2008 9

7. Selected cross sections generated from the TIN surface models of Lago Cerrillos, Ponce, Puerto Rico, for 1991 and 2008.

8. Longitudinal bottom profiles along the thalweg of Lago Cerrillos, Ponce, Puerto Rico, generated from the TIN surface models for 1991 and 2008

9. Reservoir sediment trapping efficiency as function of the ratio between water storage capacity and annual water inflow volume, Lago Cerrillos, Ponce, Puerto Rico, 2008

\section{Tables}

1. Principal characteristics of Lago Cerrillos and Cerrillos Dam, Ponce,

Puerto Rico

2. Comparison between the 1991 and the 2008 sedimentation survey results of Lago Cerrillos, Ponce, Puerto Rico

3. Relation between pool elevation and storage capacity for Lago Cerrillos, Ponce, Puerto Rico, for 2008 
Conversion Factors and Abbreviations

\begin{tabular}{|c|c|c|}
\hline Multiply & By & To obtain \\
\hline \multicolumn{3}{|c|}{ Length } \\
\hline centimeter $(\mathrm{cm})$ & 0.3937 & inch (in) \\
\hline meter $(\mathrm{m})$ & 3.281 & foot $(\mathrm{ft})$ \\
\hline kilometer $(\mathrm{km})$ & 0.6214 & mile (mi) \\
\hline \multicolumn{3}{|c|}{ Area } \\
\hline square kilometer $\left(\mathrm{km}^{2}\right)$ & 247.1 & acre \\
\hline square meter $\left(\mathrm{m}^{2}\right)$ & 10.76 & square foot $\left(\mathrm{ft}^{2}\right)$ \\
\hline square kilometer $\left(\mathrm{km}^{2}\right)$ & 0.3861 & square mile $\left(\mathrm{mi}^{2}\right)$ \\
\hline \multicolumn{3}{|c|}{ Volume } \\
\hline cubic meter $\left(\mathrm{m}^{3}\right)$ & 35.31 & cubic foot $\left(\mathrm{ft}^{3}\right)$ \\
\hline cubic meter $\left(\mathrm{m}^{3}\right)$ & 0.0008107 & acre-foot (acre-ft) \\
\hline cubic hectometer $\left(\mathrm{hm}^{3}\right)$ & 810.7 & acre-foot (acre-ft) \\
\hline \multicolumn{3}{|c|}{ Flow rate } \\
\hline cubic meter per second $\left(\mathrm{m}^{3} / \mathrm{s}\right)$ & 35.31 & cubic foot per second $\left(\mathrm{ft}^{3} / \mathrm{s}\right)$ \\
\hline liter per second (L/s) & 15.85 & gallon per minute (gal/min) \\
\hline cubic meter per second $\left(\mathrm{m}^{3} / \mathrm{s}\right)$ & 22.83 & million gallons per day $(\mathrm{Mgal} / \mathrm{d})$ \\
\hline \multicolumn{3}{|c|}{ Mass } \\
\hline $\begin{array}{l}\text { megagram per day per square } \\
\text { kilometer }\left[(\mathrm{Mg} / \mathrm{d}) / \mathrm{km}^{2}\right]\end{array}$ & 2.8547 & $\begin{array}{l}\text { ton per day per square mile } \\
{\left[(\text { ton } / \mathrm{d}) / \mathrm{mi}^{2}\right]}\end{array}$ \\
\hline
\end{tabular}

Temperature in degrees Celsius $\left({ }^{\circ} \mathrm{C}\right)$ may be converted to degrees Fahrenheit $\left({ }^{\circ} \mathrm{F}\right)$ as follows:

${ }^{\circ} \mathrm{F}=\left(1.8 x^{\circ} \mathrm{C}\right)+32$

Temperature in degrees Fahrenheit $\left({ }^{\circ} \mathrm{F}\right)$ may be converted to degrees Celsius $\left({ }^{\circ} \mathrm{C}\right)$ as follows:

${ }^{\circ} \mathrm{C}=\left({ }^{\circ} \mathrm{F}-32\right) / 1.8$

Horizontal coordinate information is "North American Datum of 1983 (NAD 83)"

Sea level: in this report, "sea level" refers to the National Geodetic Vertical Datum of 1929 (NGVD of 1929) -- a geodetic datum derived from a general adjustment of the first-order level nets of both the United States and Canada, formerly called "Sea Level Datum of 1929"

Elevation in this report refers to the measured distance above a given vertical datum. In this case is the local Puerto Rican mean sea level which is referenced to the NGVD29.

\section{Acronyms}

$\begin{array}{ll}\text { BLASS } & \text { Bathymetric/Land Survey System } \\ \text { GPS } & \text { Global Positioning System } \\ \text { GIS } & \text { Geographic Information System } \\ \text { PRASA } & \text { Puerto Rico Aqueduct and Sewer Authority } \\ \text { PRDENR } & \text { Puerto Rico Department of Natural and Environmental Resources } \\ \text { TIN } & \text { Triangulated Irregular Network } \\ \text { USACE } & \text { U.S. Army Corps of Engineers } \\ \text { USGS } & \text { U.S. Geological Survey }\end{array}$




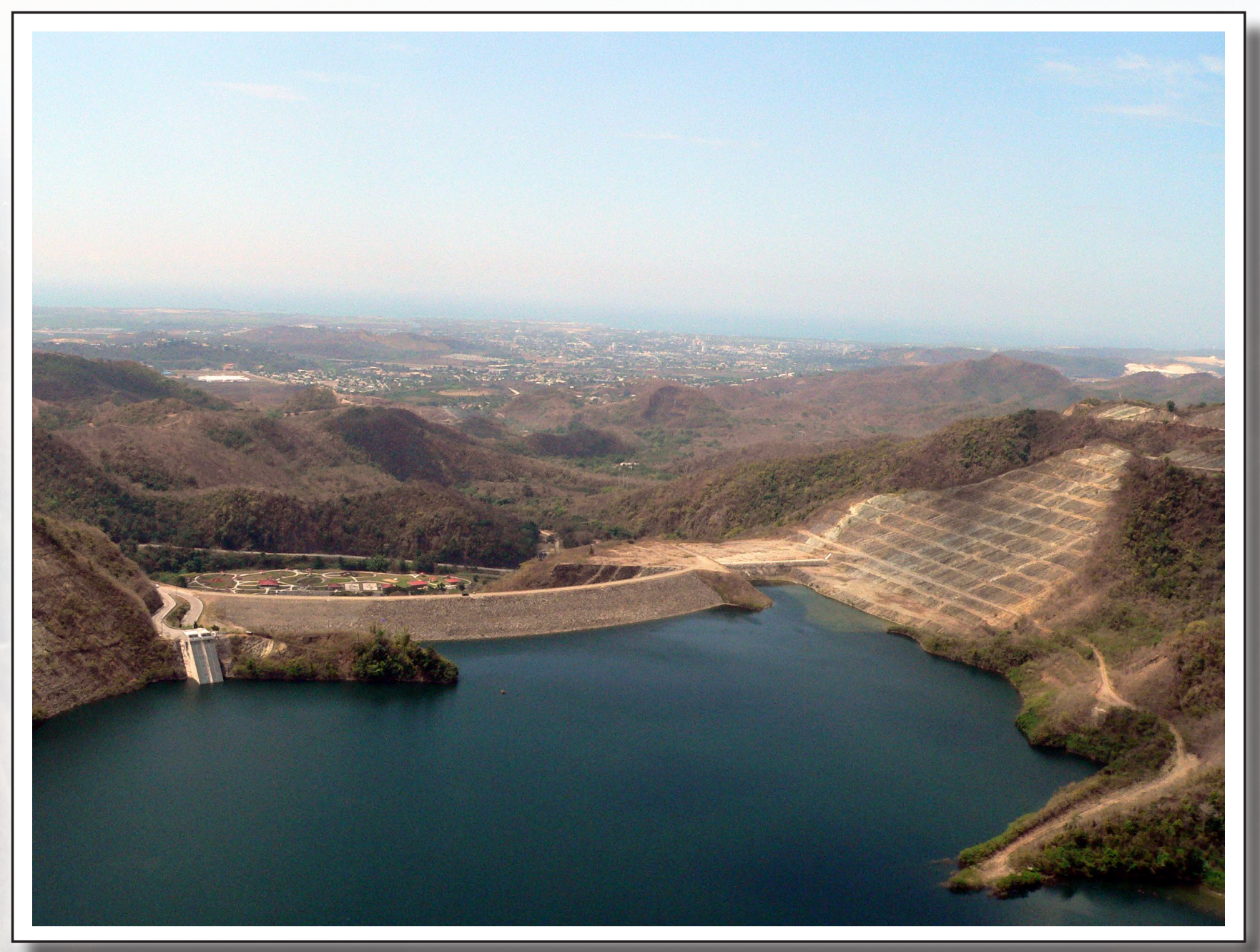

Aerial photograph of the Lago Cerrillos rockfill dam looking down stream. Photograph courtesy of the Puerto Rico Electric Power Authority, taken on May 9, 2006 


\title{
Sedimentation Survey of Lago Cerrillos, Ponce, Puerto Rico, April-May 2008
}

\author{
By Luis R. Soler-López
}

\begin{abstract}
Lago Cerrillos dam, located in the municipality of Ponce in southern Puerto Rico, was constructed in 1991 as part of the multipurpose Río Portugues and Bucaná Project. This project provides flood protection, water supply, and recreation facilities for the municipio of Ponce. The reservoir had an original storage capacity of 38.03 million cubic meters at maximum conservation pool elevation of 174.65 meters above mean sea level and a drainage area of 45.32 square kilometers.

Sedimentation in Lago Cerrillos reservoir has reduced the storage capacity from 38.03 million cubic meters in 1991 to 37.26 million cubic meters in 2008 , which represents a total storage loss of about 2 percent. During July 29 to August 23, 2002, 8,492 cubic meters of sediment were removed from the Río Cerrillos mouth of the reservoir. Taking into account this removed material, the total water-storage loss as of 2008 is 778,492 cubic meters, and the long-term annual water-storage capacity loss rate is about 45,794 cubic meters per year or about 0.12 percent per year.

The Lago Cerrillos net sediment-contributing drainage area has an average sediment yield of about 1,069 cubic meters per square kilometer per year. Sediment accumulation in Lago Cerrillos is not uniformly distributed and averages about 3 meters in thickness. This represents a sediment deposition rate of about 18 centimeters per year. On the basis of the 2008 reservoir storage capacity of 37.26 million cubic meters per year and a long-term sedimentation rate of 45,794 cubic meters per year, Lago Cerrillos is estimated to have a useful life of about 814 years or until the year 2822 .
\end{abstract}

\section{Introduction}

The Puerto Rico Department of Natural and Environmental Resources (PRDNER) owns and operates the Lago Cerrillos reservoir, located in southern Puerto Rico, within the municipio of Ponce, about 8 kilometers north of downtown Ponce (fig. 1). The dam, finished in 1991, impounds the waters of the Río Cerrillos and an unnamed creek that enters Lago Cerrillos about 2,250 meters upstream from the dam.

The reservoir is part of the Portugues-Bucaná MultiPurpose Project and was constructed as a flood control structure to attenuate the floods of the Río Cerrillos in order to protect the municipio of Ponce. Although the original plan was to use 53 percent of the water in Lago Cerrillos for public supply (U. S. Army Corps of Engineers, 1997), the plan was later abandoned because the PRDNER uses the reservoir as a recreational water body and the water level has to be at the conservation pool elevation of 174.65 meters above mean sea level in order to maintain the continued use of the Lago Cerrillos boat ramps and shore facilities. As of 2005, the Puerto Rico Aqueduct and Sewer Authority (PRASA) uses about 83,280 cubic meters per day of water for public supply for the municipio of Ponce (F. Santiago, Puerto Rico Department of Natural and Environmental Resources PRDENR, written comm., 2008), or about 30.40 million cubic meters per year, which adjusted by the annual runoff into the reservoir of 27.28 million cubic meters (Figueroa-Alamo and others, 2007) represents about 8 percent of the 2008 total storage capacity of Lago Cerrillos. 


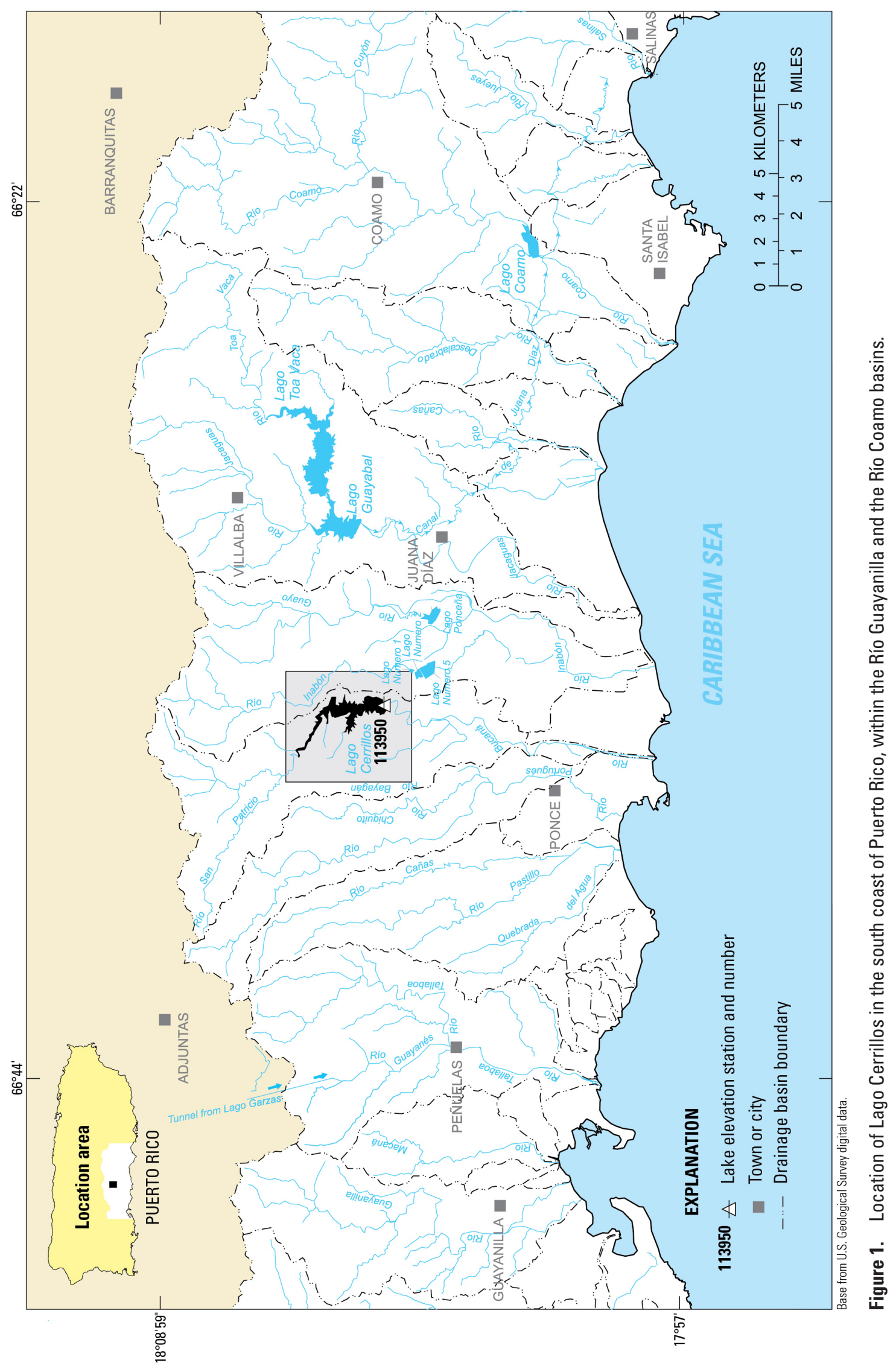


During July 29 to August 23, 2002, a private contractor removed 8,492 cubic meters of sediment from the upper reach of Lago Cerrillos, at the Río Cerrillos mouth (F. Santiago, Puerto Rico Department of Natural and Environmental Resources PRDENR, written comm., 2009). This material was part of the volume of sediment deposited in the reservoir and, therefore, needs to be accounted for in the total storage loss and rate calculations of Lago Cerrillos.

The U.S. Geological Survey (USGS) in cooperation with the Puerto Rico Aqueduct and Sewer Authority (PRASA) conducted a bathymetric survey of Lago Cerrillos during April and May 2008. The bathymetric survey was conducted by using a global positioning system (GPS) interfaced to a depth sounder. The field-collected data were then transferred into a geographic information system (GIS), which was used to determine the existing storage capacity, the sedimentation rate and sediment distribution, and to estimate the useful life of the reservoir.

The purpose of this report is to provide information that can be used to effectively plan and manage the water resources available for public water supply for the municipio of Ponce, to define the historical long-term sedimentation rates and storage capacity loss, and to provide an accurate bathymetric surface map for future reference. In addition, the updated water-storage capacity provides a management tool that can be used to determine the water renewal rate in the reservoir for the operation of the Lago Cerrillos recreational and ecological conservation activities.

\section{Description of Cerrillos Dam and Reservoir, and General Basin Characteristics}

The construction of the Cerrillos Dam started in 1984 and was completed in 1991. The Lago Cerrillos impounds streamflow from the Río Cerrillos and an unnamed tributary. The reservoir was built to provide flood control, water for public supply, and a natural recreational area for the city/ municipo of Ponce.

The dam is located about 8 kilometers north of downtown Ponce and about 4 kilometers downstream from the confluence of the Río San Patricio and Río Cerrillos (fig. 1). The dam is a rockfill structure with a height of 98.45 meters and a length of 473.96 meters. The spillway is located at the right abutment and is an ungated overflow structure with a width of 120.09 meters at an elevation of 186.32 meters above mean sea level. The dam was designed to have a maximum discharge of 2,132 cubic meters per second. An outlet works tunnel is located at the left abutment as an inclined control intake structure at an invert elevation of 105.16 meters above mean sea level. The tunnel is 434.34 meters in length, 5.49 meters in diameter, and has a maximum discharge capacity of 70.80 cubic meters per second (U.S. Army Corps of Engineers, 1997).

The reservoir originally provided about 38.03 million cubic meters of storage capacity at the conservation pool elevation of 174.65 meters above mean sea level. The document of the U.S. Army Corps of Engineers (USACE) indicates that an additional water storage of 19.70 million cubic meters between elevations of 174.65 and 186.32 meters above mean sea level is allocated for the detention storage of floodwaters, and that between elevations of 186.32 and 191.84 meters above mean sea level an additional 10.72 million cubic meters of surcharge storage of floodwater is available (U.S. Army Corps of Engineers, 1997). Therefore, the original total storage capacity of Lago Cerrillos at maximum pool elevation of 191.84 meters above mean sea level is 68.45 million cubic meters.

Volume calculations derived from the triangulated irregular network (TIN) generated from the pre-impounded topography of Lago Cerrillos, however, yielded a total storage capacity for Lago Cerrillos of 70.20 million cubic meters at maximum pool elevation of 191.84 meters above mean sea level. The difference between the volumes calculated using two methods is about 2 percent, which is considered negligible and within the method standard deviation, and does not detract from a comparison of Lago Cerrillos volumes at 174.65 meters above mean sea level. The principal characteristics of Lago Cerrillos dam and structures are presented in table 1.

The Lago Cerrillos drainage area was used predominantly for the cultivation of coffee until the early part of the 1950s (Gaztambide-Vega and Arán, 1959). Agricultural activities then reverted to the traditional localized cultivation of food crops, shaded coffee plantations, and pasture. In addition, the soils have been populated with brushes and trees.

The Lago Cerrillos drainage area general soil-type classification is within the Caguabo-Mucara-Quebrada association (Gierboloni, 1979). This soil association extends from east to west from the town of Coamo to the town of Guayanilla. The Caguabo soils are loamy and shallow to hard rock. Caguabo soils are well drained and are present mainly on very steep slopes. The Mucara soils are clayey and moderately deep to volcanic rock and are present on moderately steep to very steep slopes. The Quebrada soils are loamy and deep to volcanic rock and are present on foot slopes, side slopes, and ridges. The slopes severely limit the use of these soils for cultivation/development. In general, these types of soils are highly erodible mainly because of the steep slopes; however, the vegetation cover and very little cultivation/development within the Lago Cerrillos drainage area have kept erosion rates to a minimum.

Annual rainfall in the Ponce area averages 89 centimeters, whereas upstream from the Lago Cerrillos dam rainfall is about 203 centimeters. The typical wet season is May to November and mainly is the result of tropical cyclone activity and cold fronts (U.S. Army Corps of Engineers, 1997). 
Table 1. Principal characteristics of Lago Cerrillos and Cerrillos Dam, Ponce, Puerto Rico.

[Modified from the U. S. Army Corps of Engineers, 1997; all elevations are referenced to mean sea level]

\begin{tabular}{lc}
\hline Total length of dam & 473.96 meters \\
\hline Length of spillway section & 120.09 meters \\
\hline Maximum height of dam & 98.45 meters \\
\hline Outlet work tunnel length & 434.34 meters \\
\hline Diameter of outlet works tunnel & 5.49 meters \\
\hline Conservation pool elevation & 174.65 meters \\
\hline Elevation of crest of spillway & 186.32 meters \\
\hline Maximum pool elevation & 191.84 meters \\
\hline Maximum discharge of outlet works tunnel & 70.80 cubic meters per second \\
\hline Design discharge of overflow spillway & $2,132 \quad$ cubic meters per second \\
\hline Original total water storage capacity at maximum pool elevation & 68.45 million cubic meters \\
\hline Original spillway crest-level water storage (flood control) & 57.74 million cubic meters \\
\hline Original maximum conservation pool elevation storage capacity & 38.03 million cubic meters \\
\hline Surcharge storage & 10.72 million cubic meters \\
\hline Drainage area at damsite & 45.32 square kilometers \\
\hline Maximum original depth at conservation pool elevation & 65.00 meters \\
\hline Maximum depth during the 2008 survey at conservation pool elevation & 65.00 meters \\
\hline
\end{tabular}

\section{Method of Survey}

The 2008 bathymetric survey of Lago Cerrillos involved planning, data collection, data processing, and data analysis. An Arc/Info GIS was used to establish the survey lines and to analyze the collected data. Survey lines were planned at a spacing of 25 meters, commencing at the dam and continuing upstream along the Lago Cerrillos thalweg (fig. 2). Bathymetric data were collected using a depth sounder coupled to a global positioning system (GPS) receiver to aid in the control of the horizontal position of the survey boat. A georeferenced digital map of the reservoir shoreline and planned survey lines were loaded into the portable personal computer and served as the guide for bathymetric data collection. The reservoir pool elevation was monitored at the continuous recording USGS lake-level monitoring station Lago Cerrillos at Damsite, near Ponce, Puerto Rico, station number 50113950 (shortened to 113950 in fig. 1). The pool elevation of Lago Cerrillos was not at the conservation pool elevation; therefore, the sounding data were adjusted using a time-elevation correction factor to represent depths at elevation of 174.65 meters above mean sea level. The time-elevation adjustment ranged from 1.67 to 2.33 meters.
A total of 35,559 data points (depth soundings with geographic coordinates) were collected over the entire reservoir while navigating along the planned survey lines (fig. 3). The depths along the cross sections were plotted, and 5 -meter interval contour lines of equal depth were drawn from the shoreline to the deepest parts of the reservoir (plate 1). The procedure used to contour the reservoir bottom is explained in the "Data Processing" section of this report. The contour lines were then converted into a TIN depicting the surface model of the reservoir bottom (fig. 4). The TIN represents the reservoir bottom surface model as thousands of adjoining triangles with $\mathrm{x}, \mathrm{y}$, and $\mathrm{z}$ coordinates assigned to all vertices (Environmental Systems Research Institute, Inc. 1992). The longitudinal distance of Lago Cerrillos along the thalweg, shown in figure 5 , delineates the reservoir bottom in the deepest part from the dam up to the river mouth.

The 1991 reservoir storage capacity was compared with the 2008 storage capacity to obtain estimates of historical sediment accumulation rates and to estimate the useful life of the reservoir. The relation between pool elevation and reservoir storage capacity for 1991 and 2008 was generated by calculating the reservoir volume at 1 -meter elevation intervals (fig. 6). 


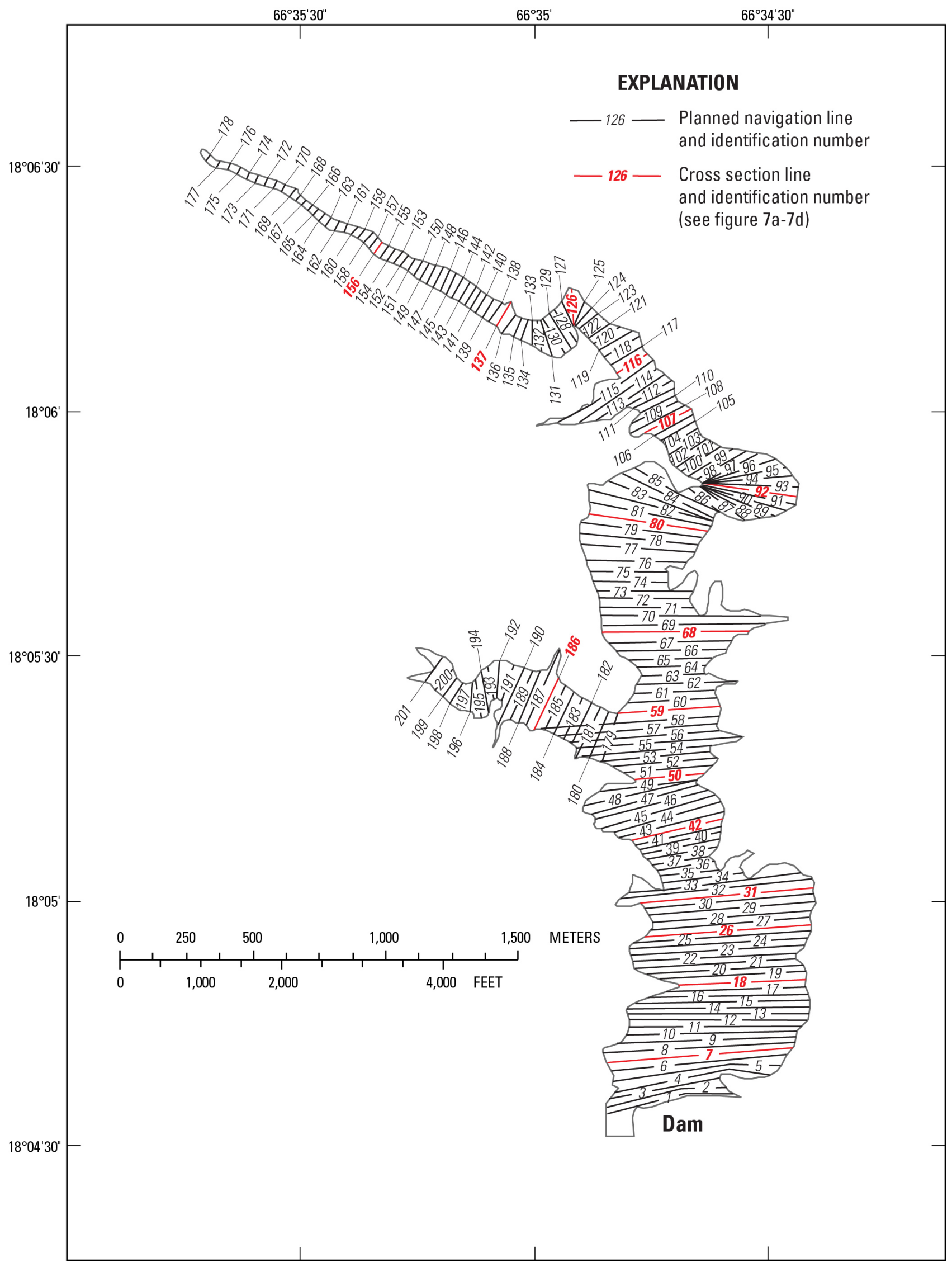

Figure 2. Planned survey lines for the April-May 2008, bathymetric survey of Lago Cerrillos, Ponce, Puerto Rico. 


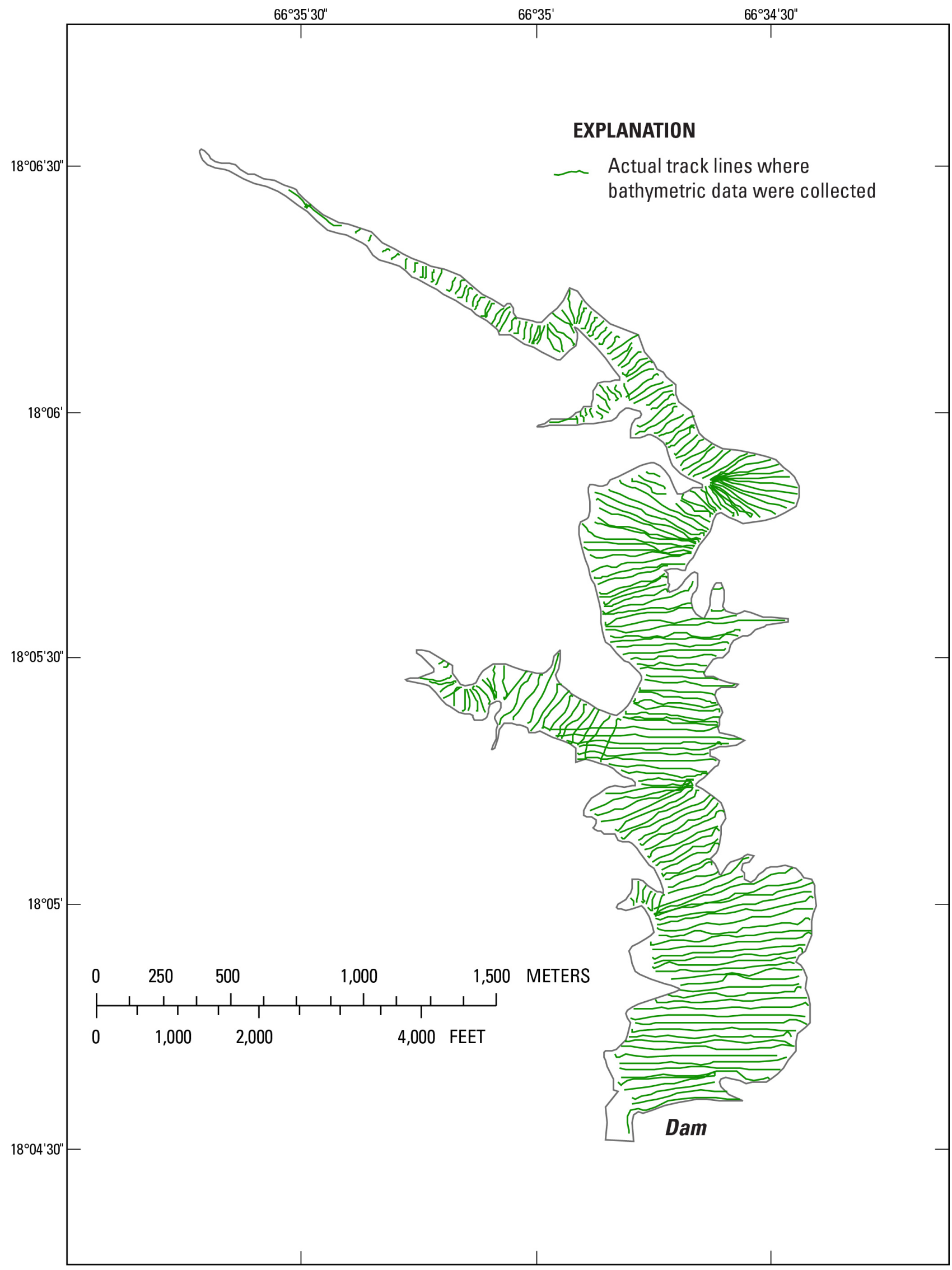

Figure 3. Actual track lines where bathymetric data were collected in Lago Cerrillos, Ponce, Puerto Rico, April-May 2008. 


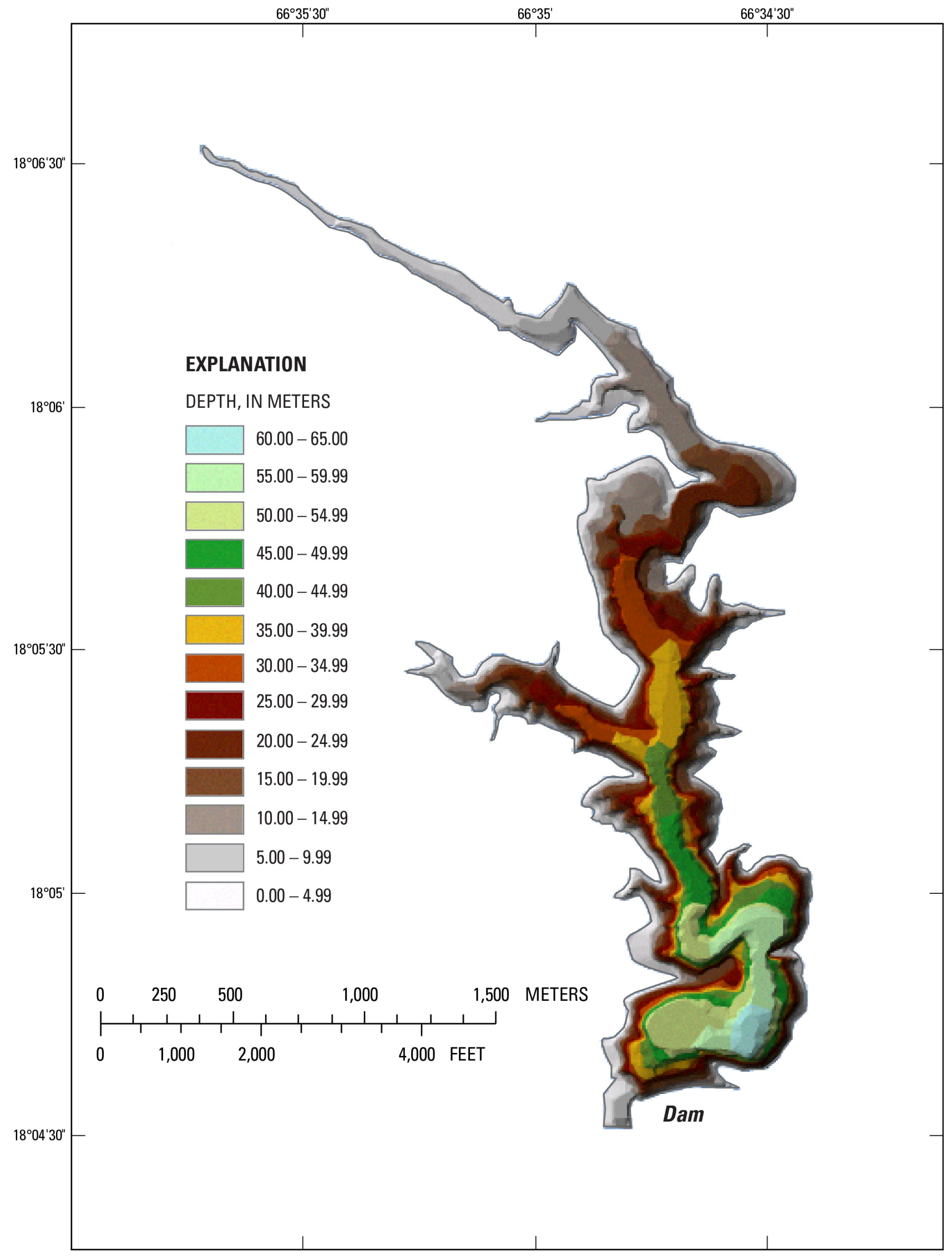

Figure 4. Triangulated irregular network (TIN) surface model of Lago Cerrillos, Ponce, Puerto Rico, 2008. 


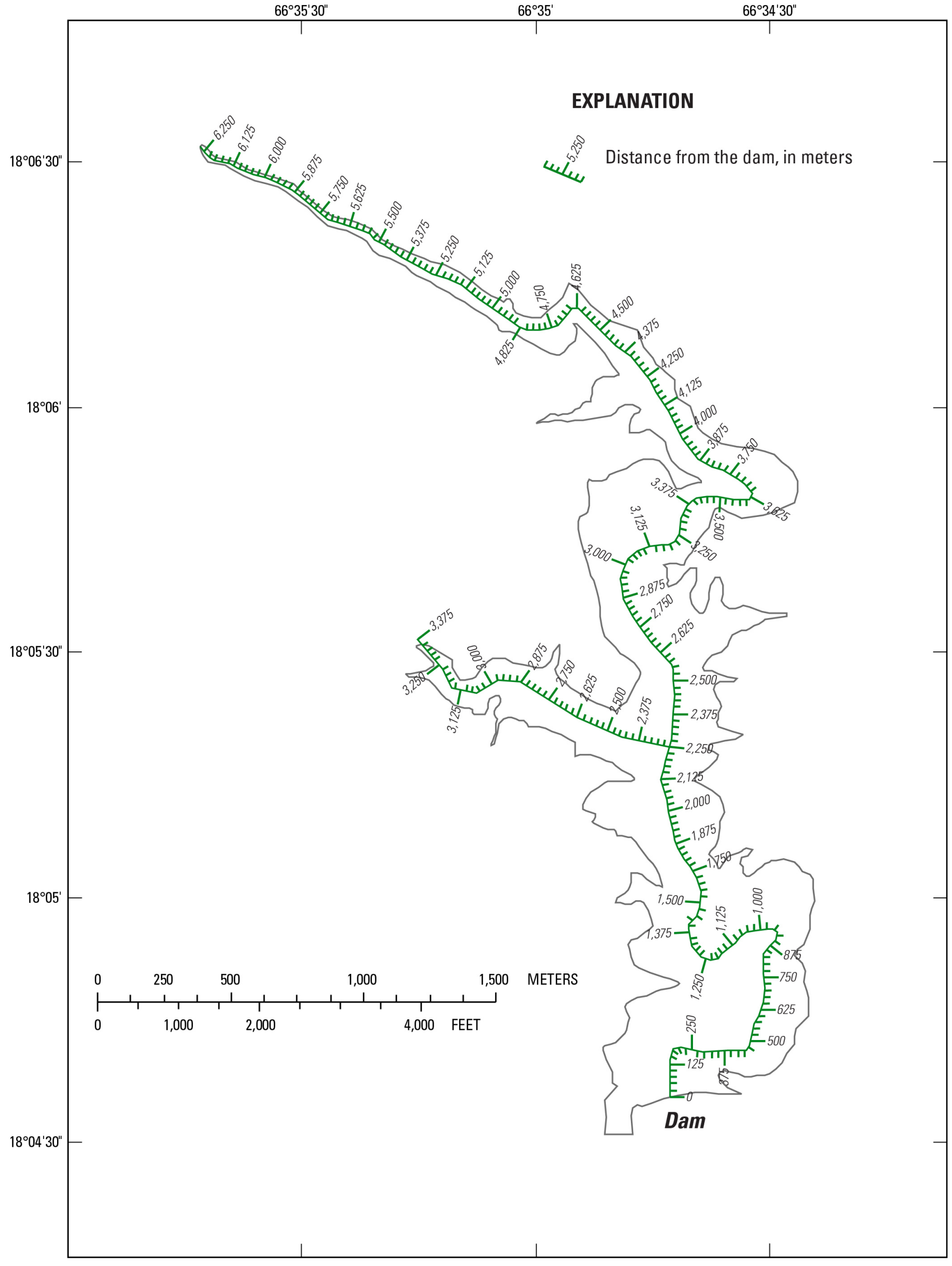

Figure 5. Reference longitudinal distance along the thalweg of Lago Cerrillos, Ponce, Puerto Rico, 2008. 


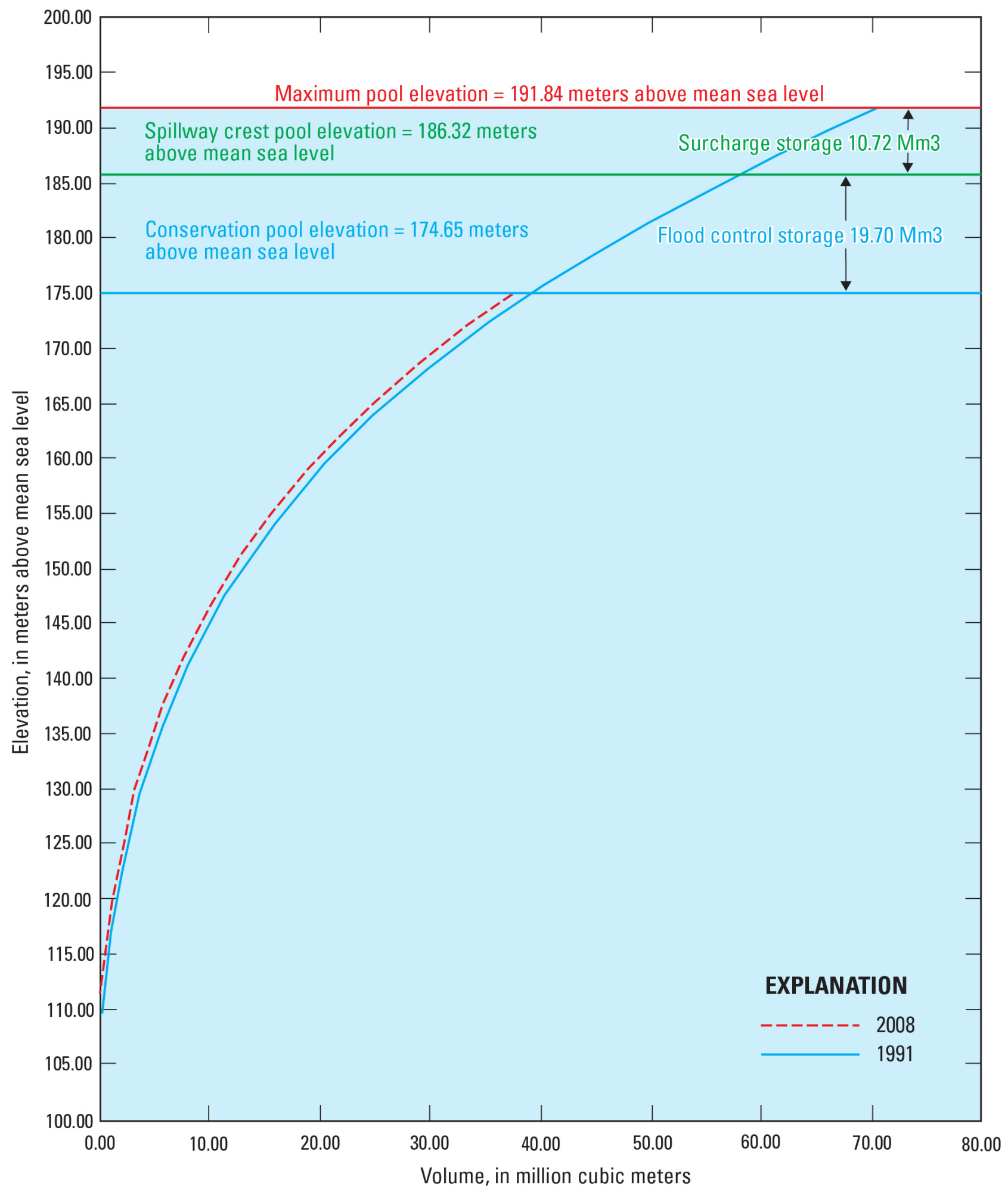

Figure 6. Relation between reservoir pool elevation and water-storage capacity of Lago Cerrillos, Ponce, Puerto Rico, for 1991 and 2008. 


\section{Field Techniques}

The bathymetric survey of Lago Cerrillos was conducted from April 28 to May 1, 2008. Data were collected using the bathymetric/land survey system (BLASS) developed by Specialty Devices, Inc. The system consists of a Novatel ${ }^{\circledR}$ global positioning system (GPS) receiver coupled to an SDIIntelligent model depth sounder. The GPS receiver monitors the horizontal position of the survey boat while the depth sounder collects data on water depths. The bathymetric survey software HYPACK was used to navigate and to collect data. The software integrates the depth and position data, storing the $\mathrm{x}, \mathrm{y}$, (geographic location) and $\mathrm{z}$ (depth) coordinates in a portable personal computer.

A total of 201 survey sounding lines were planned in the office using the GIS (fig. 2); however, in the field additional ancillary sections were navigated to better define the Lago Cerrillos bottom topography for a grand total of 245 survey lines collected (fig. 3).

\section{Data Processing}

Operation procedures for the Lago Cerrillos sedimentation survey require that the reservoir pool elevation is kept at or near the conservation pool elevation of 174.65 meters above mean sea level in order for the reservoir to serve as a flood control project, so the water level should not exceed this elevation. Therefore, in order to standardize all the data collected during the 2008 bathymetric survey of Lago Cerrillos, the reservoir volume was calculated at elevation of 174.65 meters above mean sea level for both 1991 and 2008.

The data processing for the 2008 Lago Cerrillos sedimentation survey consisted of two major components: (1) input of the original 1991 pre-impounded topography into the USGS GIS database and (2) editing and transferring of the 2008 bathymetric survey data into the USGS GIS database.

The original pre-impoundment topography of Lago Cerrillos in the form of a hard-copy map was provided by the USACE, which constructed the reservoir and dam. The map was scanned, digitized, converted into Arc/Info coverage and loaded into the GIS database; then a TIN was generated for 1991. From the TIN, the original volume of the reservoir was calculated using the GIS at elevations of $174.65,186.32$, and 191.84 meters (table 1).

Editing and initial processing of the 2008 data were performed using the HYPACK software. Positions were corrected to eliminate anomalies that occur when the satellite signal is lost because of local topographic features or electromagnetic interference. Position errors were corrected by interpolating back to the middle point between the correct antecedent and preceding position. The depth data also were corrected to eliminate incorrect depth readings that can result from insufficient signal gain or because floating debris interferes with the transducer face. The incorrect depth readings were interpolated between the correct antecedent and precedent depth readings. Once corrected, the edited data were transferred into the GIS database for further processing. The Arc/Info software was customized to color-code the depth data according to different depth intervals. Data points of the same color code were connected by adding a line between them, and a contour map of the reservoir bottom depth was generated (plate 1). The bathymetric contour map was used to create the TIN surface model of the reservoir bottom for 2008 (fig. 4).

Transverse profiles representing the reservoir bottom from shore to shore for 1991 and 2008 were generated by sampling the TIN every 5 meters along selected cross sections (fig. 7). The same procedure used to generate the selected cross-section profiles was used to generate the longitudinal profiles along the thalweg of Lago Cerrillos for the same years (fig. 8). Locations of selected cross sections were chosen to represent flooded areas of the reservoir, whereas locations of longitudinal profiles were chosen to represent the deepest part of the reservoir bottom from the dam up to the tributary river mouth.

\section{Sediment Accumulation and Effect on Reservoir Storage}

The original water-storage capacity of Lago Cerrillos was 38.03 million cubic meters at conservation pool elevation of 174.65 meters above mean sea level. The results of the 2008 sedimentation survey of Lago Cerrillos indicate that the reservoir storage capacity is 37.26 million cubic meters for a total storage loss of 770,000 cubic meters, which represents a total storage loss of about 2 percent. However, taking into account the sediment removed in 2002, the total storage loss is in reality 778,492 cubic meters. This represents a Lago Cerrillos long-term sedimentation rate of 45,794 cubic meters per year or a water-storage loss of about 0.12 percent per year. The Lago Cerrillos sedimentation rate of 45,794 cubic meters per year is low compared to other principal reservoirs in Puerto Rico (for example, the rates for Lago Loíza and Lago Dos Bocas are about 300,000 cubic meters per year). A comparison of the original 1991 and 2008 sedimentation surveys of Lago Cerrillos is presented on table 2.

The Lago Cerrillos water-intake structure used for outlet releases is located at the upstream face of the dam at an elevation of 137.46 meters above mean sea level. The volume of water contained above the elevation of the intake structure is referred to as the live (useful) storage, and the volume below it is referred to as the dead storage, which is used to accommodate sediment without disabling the reservoir operation. In 1991, the live storage of Lago Cerrillos was about 31.08 million cubic meters, and the dead storage about 6.95 million cubic meters (table 2). For 2008, the live storage remained equal, whereas the dead storage was reduced to 6.18 million cubic meters, indicating that the water storage loss in Lago Cerrillos has occurred only in the dead storage fraction. This is beneficial because all of the useful water volume of 
Table 2. Comparison between the 1991 and the 2008 sedimentation survey results of Lago Cerrillos, Ponce, Puerto Rico.

All data are referenced to the conservation pool elevation of 174.65 meters above mean sea level, — undetermined]

\begin{tabular}{lcc}
\hline \multicolumn{1}{c}{ YEAR } & $\mathbf{1 9 9 1}$ & $\mathbf{2 0 0 8}$ \\
\hline Reservoir surface area, in square kilometers & 11.42 & ${ }^{2} 1.60$ \\
Capacity, in million cubic meters at conservation pool elevation & 38.03 & 37.26 \\
Live storage, at conservation pool elevation in million cubic meters & 31.08 & 31.08 \\
Dead storage, in million cubic meters & 36.95 & 6.18 \\
Dead storage loss, in million cubic meters & 0 & 0.77 \\
Years since construction & 0 & 17 \\
Sediment accumulated, in cubic meters & 0 & 778,492 \\
Long-term storage loss, in percent & 0 & 2.05 \\
Annual loss of capacity, in percent & 0 & 0.12 \\
Long-term annual loss of capacity, in million cubic meters & 0 & 45,794 \\
Sediment trapping efficiency, in percent & 98 & 98 \\
Long-term sediment yield, in cubic meters per square kilometer per year & 0 & 1,069 \\
Year the reservoir would fill with sediments & - & 2822 \\
\hline
\end{tabular}

${ }^{1}$ As reported in U. S. Army Corps of Engineers, 1997

${ }^{2}$ Calculated using the geographic information system

${ }^{3}$ As reported in U. S. Army Corps of Engineers, 1997

Lago Cerrillos is still available. The relation between reservoir pool elevation and water storage capacity for Lago Cerrillos for May 2008 are listed in table 3.

Sediment accumulation within Lago Cerrillos is noticeable at an area that extends from about 800 to 1,200 meters upstream from the dam where 3 meters of sediment have been deposited. In this area, the reservoir bottom morphology (original river channel) makes a couple of consecutive abrupt meanders, which slows water velocities during floods promoting sediment deposition (fig. 5; plate 1). In the rest of Lago Cerrillos no sediment accumulation is noticeable.

\section{Lago Cerrillos Sediment Trapping Efficiency and Water Renewal Rate}

Heinemann (1981) considered sediment trapping efficiency to be the most informative descriptor of a reservoir because it basically controls the sediment deposition and consequent storage loss in a reservoir. This value is the proportion of the incoming sediment that is deposited or trapped in a pond, reservoir, or lake. Sediment trapping efficiency is dependent on several characteristics, including sediment particle size, distribution, time and rate of water inflow to the reservoir, reservoir size and shape, location of the outlet structure, and location and discharge schedules (Verstraeten and Poesen, 2000).
Many empirical studies showing the relations among reservoir storage capacity, water inflow, and trapping efficiency have been conducted in the past, of which Brune's (1953) relation is the most widely used and accepted. Brune developed a curve used to estimate the sediment trapping efficiency of a reservoir on the basis of the ratio of storage capacity to annual water inflow volume. The trapping efficiency of Lago Cerrillos was estimated using the relation established by Brune (1953). Because no particle-size distribution analysis was performed on the reservoir's bottom sediments, the median curve of Brune's relation was used. On the basis of the 2008 storage capacity of 37.26 million cubic meters and a mean annual runoff of 27.28 million cubic meters (Figueroa-Alamo and others, 2007), the capacity to inflow ratio is 1.37 for 2008. Extrapolating this value in Brune's curve, the trapping efficiency, using relations established by Brune (1953), is about 98 percent (fig. 9).

The mean annual water withdrawal rate of 30.40 million cubic meters is the controlling mechanism in water renewal rate of Lago Cerrillos because this withdrawal cancels the net annual water inflow volume of 27.28 million cubic meters. On the basis of the annual withdrawal rate of 30.40 million cubic meters and the 2008 reservoir storage capacity of 37.26 million cubic meters, it takes about 1.2 years for the reservoir to renew its entire water volume. This estimate, however, does not take into account extreme runoff events that could flush Lago Cerrillos in a short period. 


\section{Sedimentation Survey of Lago Cerrillos, Ponce, Puerto Rico, April-May 2008}

Table 3. Relation between pool elevation and storage capacity for Lago Cerrillos, Ponce, Puerto Rico, for 2008.

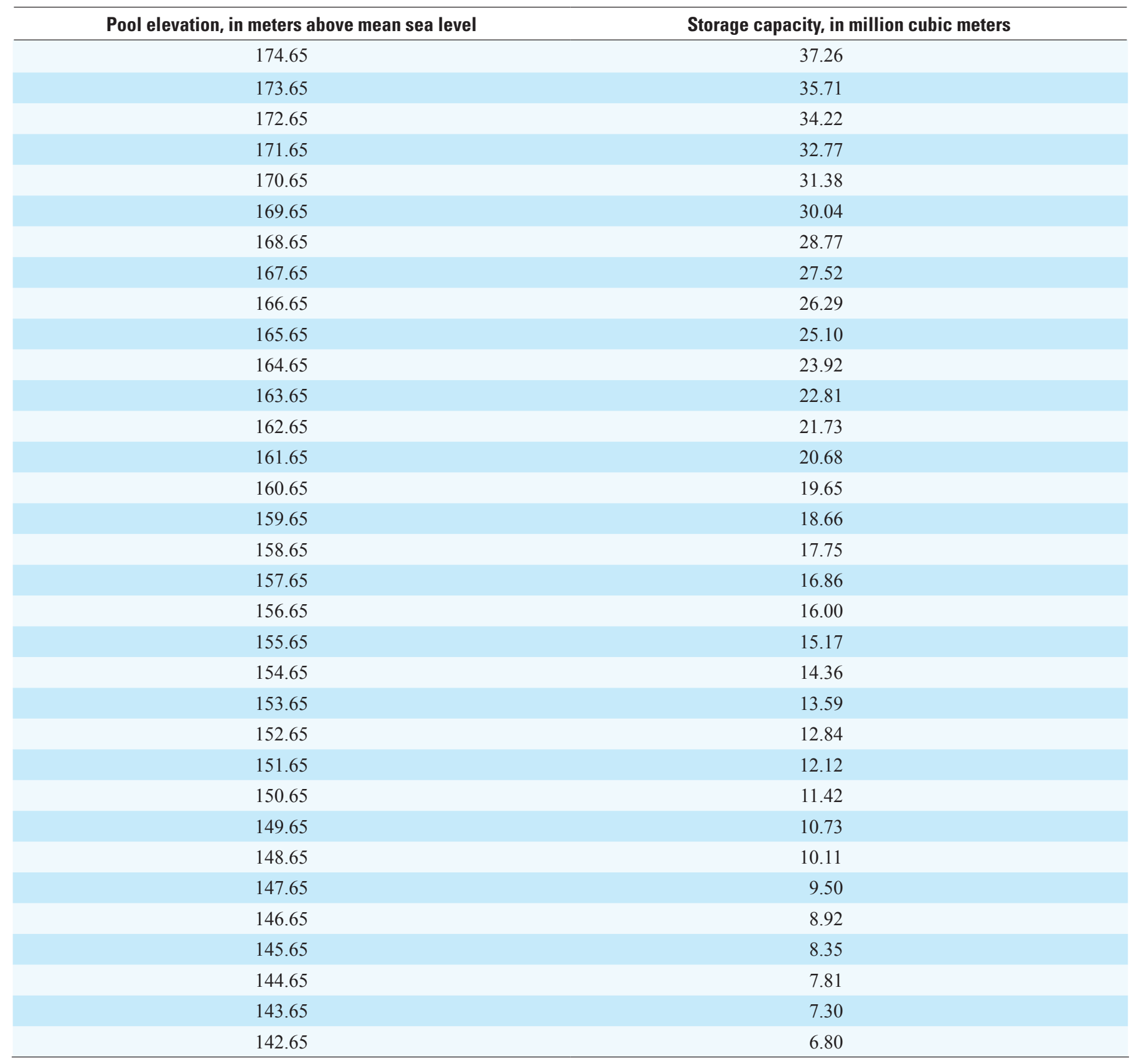


Table 3. Relation between pool elevation and storage capacity for Lago Cerrillos, Ponce, Puerto Rico, for 2008.-Continued

\begin{tabular}{|c|c|}
\hline Pool elevation, in meters above mean sea level & Storage capacity in million cubic meters \\
\hline 141.65 & 6.32 \\
\hline 140.65 & 5.86 \\
\hline 138.65 & 5.02 \\
\hline 137.65 & 4.64 \\
\hline 135.65 & 3.92 \\
\hline 134.65 & 3.59 \\
\hline 133.65 & 3.29 \\
\hline 132.65 & 3.00 \\
\hline 128.65 & 1.97 \\
\hline 127.65 & 1.75 \\
\hline 126.65 & 1.54 \\
\hline 125.65 & 1.34 \\
\hline 124.65 & 1.15 \\
\hline 123.65 & 0.99 \\
\hline 122.65 & 0.83 \\
\hline 121.65 & 0.69 \\
\hline 114.65 & 0.07 \\
\hline 113.65 & 0.05 \\
\hline 112.65 & 0.03 \\
\hline 111.65 & 0.02 \\
\hline 110.65 & 0.01 \\
\hline 109.65 & 0.00 \\
\hline
\end{tabular}




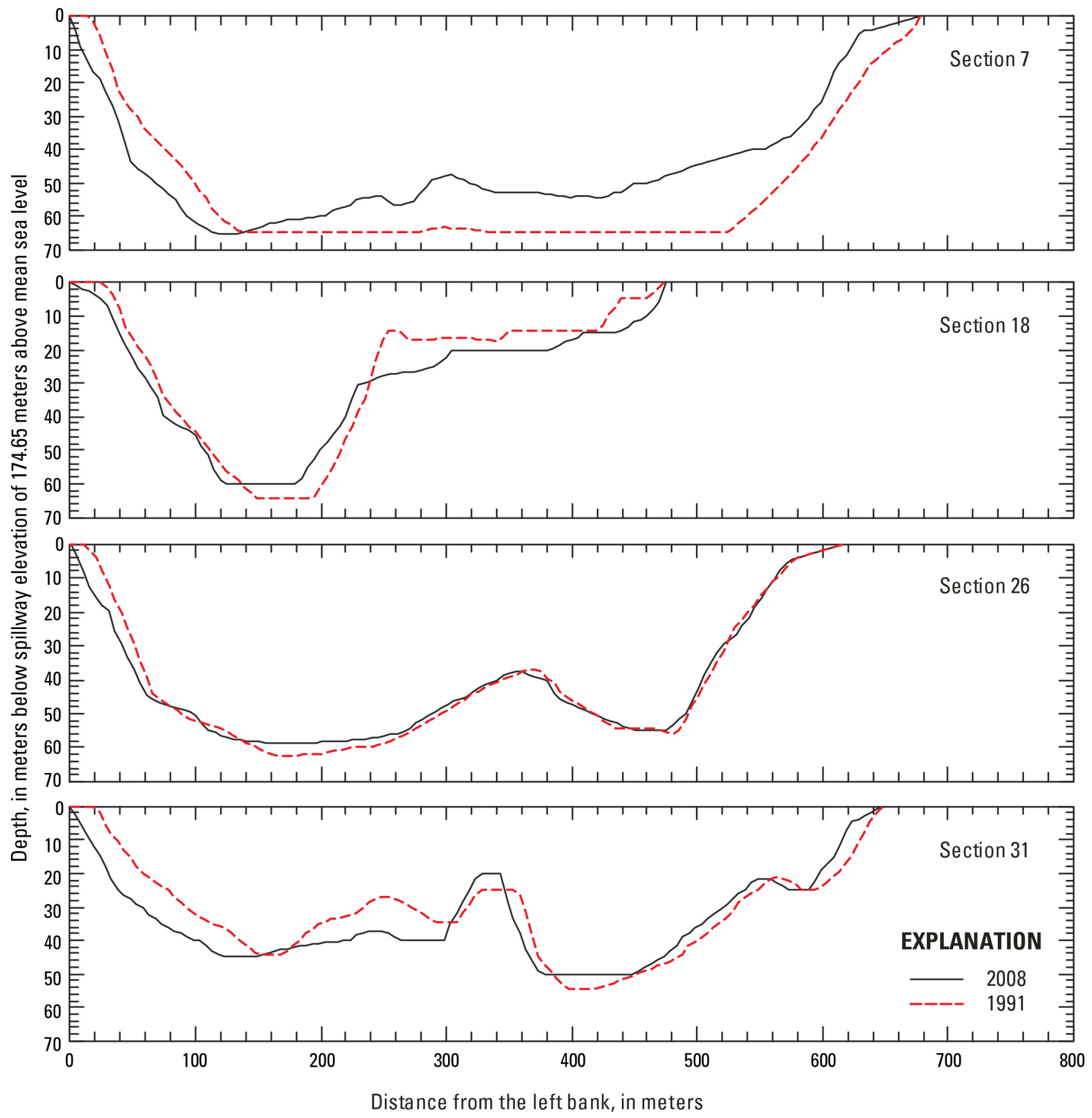

Figure 7. Selected cross sections generated from the TIN surface models of Lago Cerrillos, Ponce, Puerto Rico, for 1991 and 2008. (Refer to figure 2 cross section locations). 


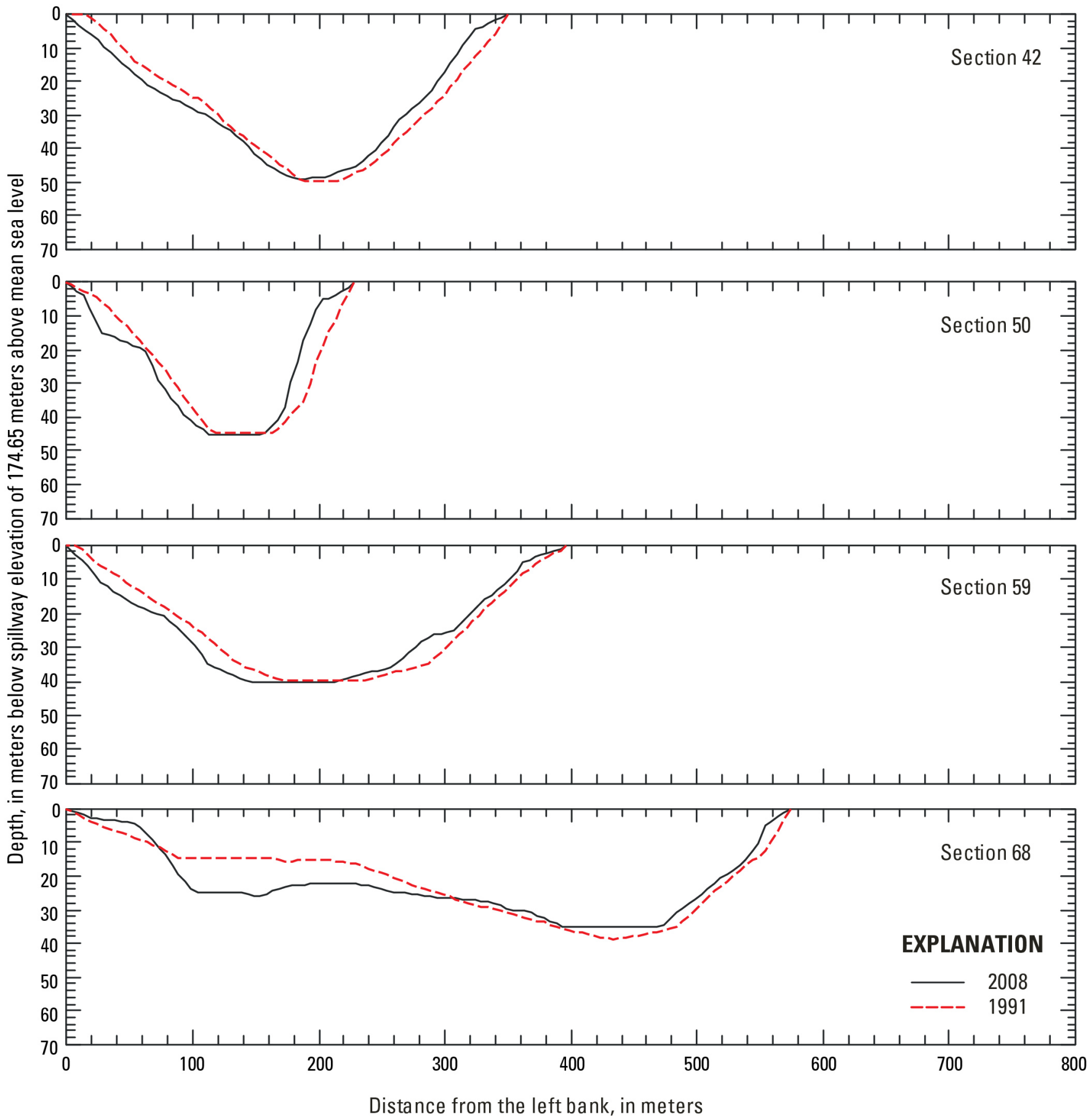

Figure 7. Selected cross sections generated from the TIN surface models of Lago Cerrillos, Ponce, Puerto Rico, for 1991 and 2008. (Refer to figure 2 cross section locations).-Continued 


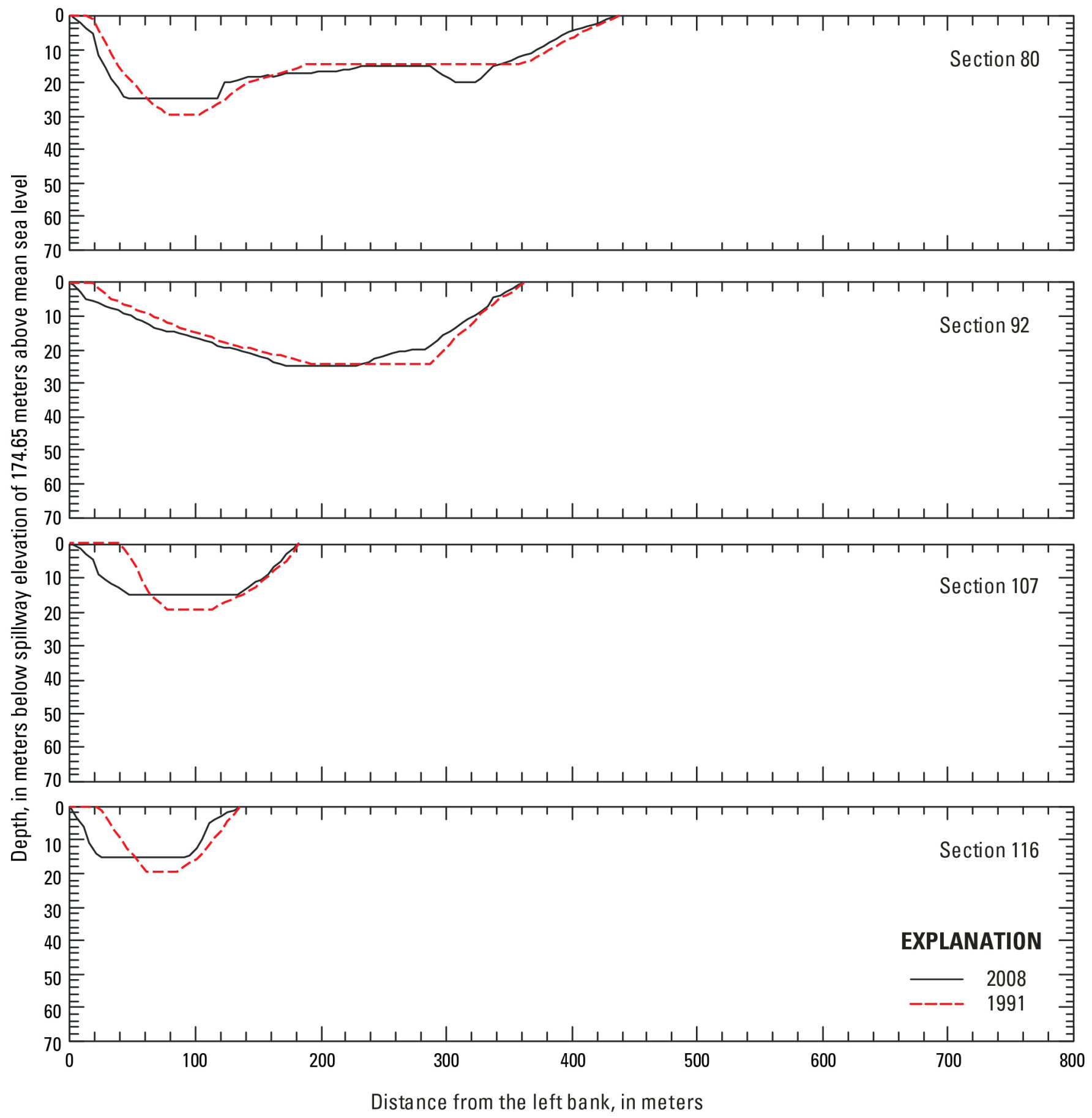

Figure 7. Selected cross sections generated from the TIN surface models of Lago Cerrillos, Ponce, Puerto Rico, for 1991 and 2008. (Refer to figure 2 cross section locations).-Continued 


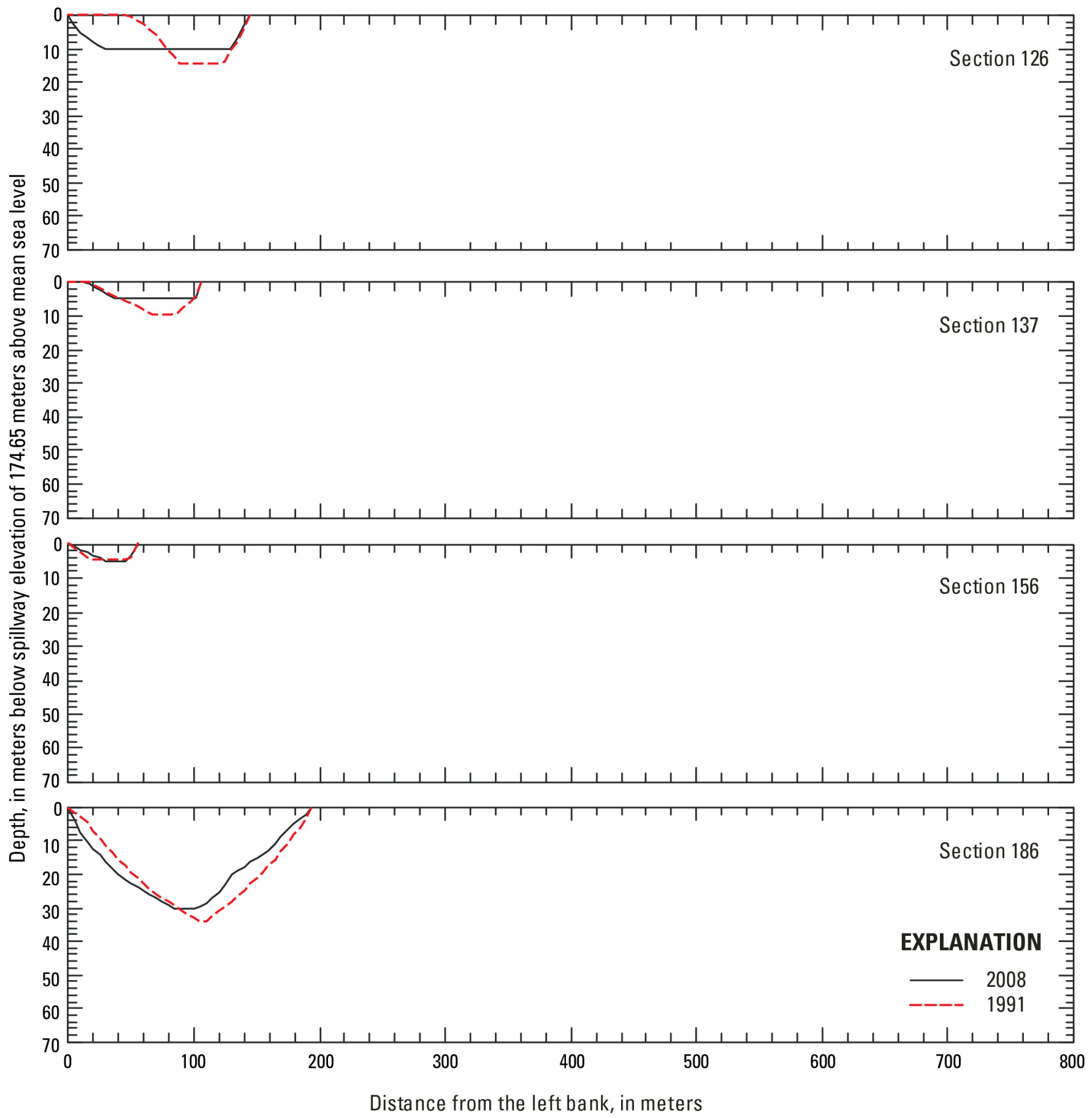

Figure 7. Selected cross sections generated from the TIN surface models of Lago Cerrillos, Ponce, Puerto Rico, for 1991 and 2008. (Refer to figure 2 cross section locations).-Continued 


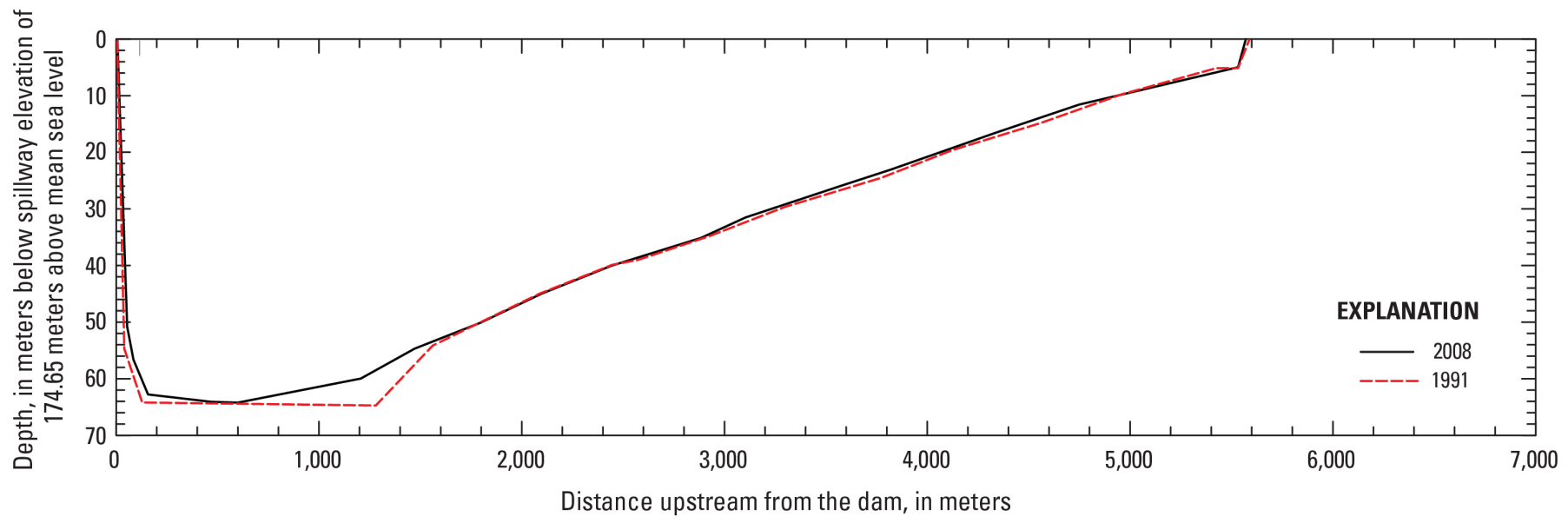

Figure 8. Longitudinal bottom profiles along the thalweg of Lago Cerrillos, Ponce, Puerto Rico, generated from the TIN surface models for 1991 and 2008.

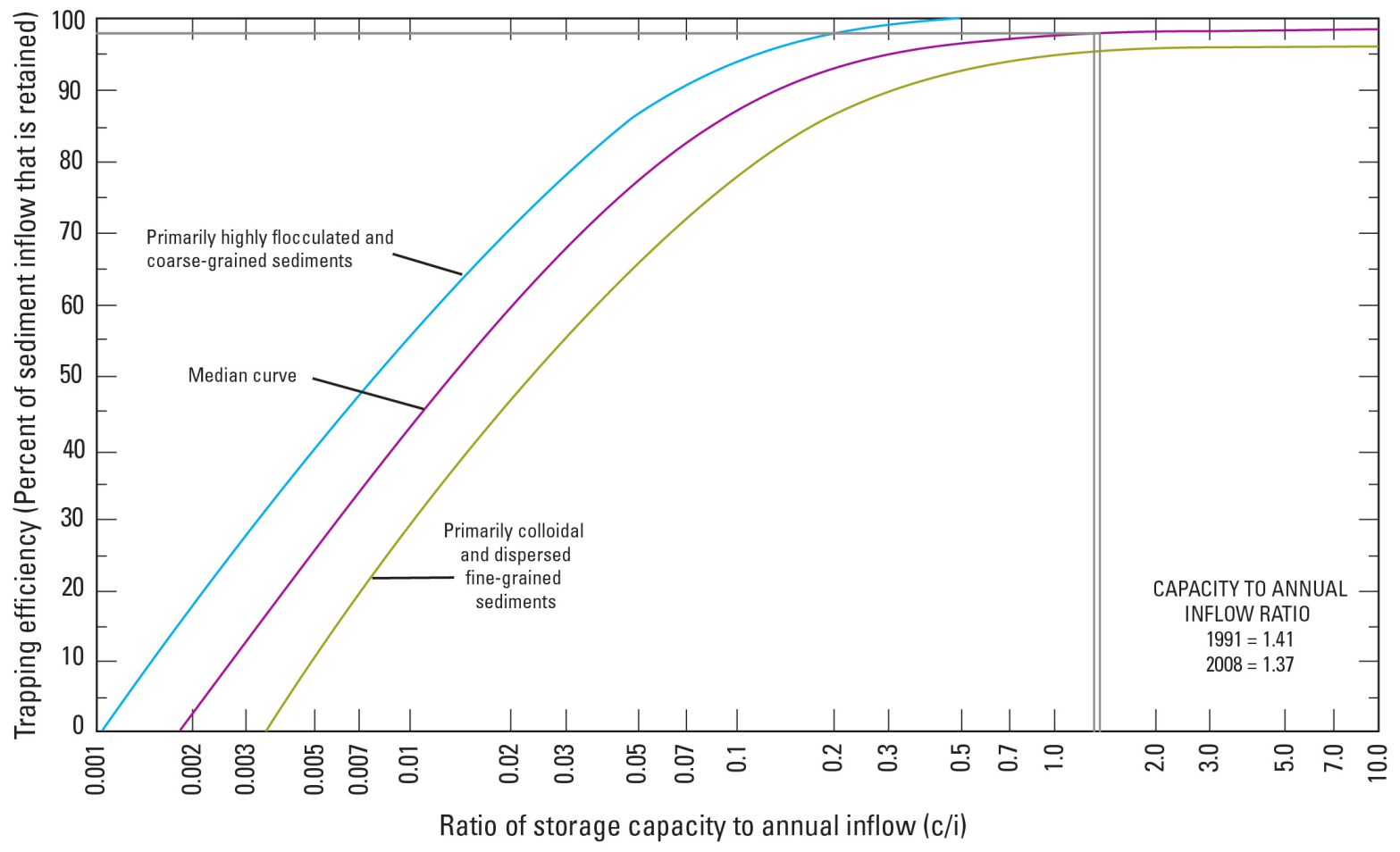

Figure 9. Reservoir sediment trapping efficiency as function of the ratio between water storage capacity and annual water inflow volume, Lago Cerrillos, Ponce, Puerto Rico, 2008. 


\section{Lago Cerrillos Drainage Area Sediment Yield and Reservoir Life Expectancy}

Sediment yield has been defined by the American Society of Civil Engineers as the total sediment outflow from a catchment or drainage basin, measurable at a point of reference over a specified period of time, per unit of surface area (McManus and Duck, 1993). The amount of sediment accumulated in the reservoir by 2008 (778,492 cubic meters) divided by the long-term average trapping efficiency of the reservoir ( 98 percent) and by the net sediment-contributing drainage area of the reservoir (43.72 square kilometers, the total drainage area minus the reservoir surface area) gives the volume of sediment transported from the basin per unit of area and accumulated in the reservoir $(18,170$ cubic meters per square kilometer). This value divided by the number of years since impoundment (17), gives the long-term sediment yield of the drainage area, approximately 1,069 cubic meters per square kilometer per year.

The life expectancy of Lago Cerrillos, or any other reservoir, can be estimated by dividing the remaining storage capacity by the long-term annual storage capacity loss. On the basis of the average reservoir storage capacity loss between 1991 and 2008 of about 45,794 cubic meters per year, the reservoir would be completely filled with sediment in about 814 years from 2008 or by 2822 .

\section{Summary and Conclusions}

The April-May 2008 bathymetric sedimentation survey of Lago Cerrillos was conducted by the USGS in cooperation with PRASA using state-of-the-art technology. The bathymetric survey indicates that the reservoir has lost about 0.77 million cubic meters of water or 2 percent of the original storage capacity since it was completed in 1991. This represents a long-term storage loss rate of about 45,800 cubic meters per year or about 0.12 percent per year.

The Lago Cerrillos current sediment trapping efficiency is high at 98 percent. On the basis of the annual withdrawal rate of 30.40 million cubic meters of water and the 2008 reservoir storage capacity of 37.26 million cubic meters, it takes about 1.2 years for the reservoir to renew its entire water volume.

Sediment accumulation in Lago Cerrillos is noticeable only in an area about 800 to 1,200 meters upstream from the dam and has affected only the dead storage fraction of the reservoir, which is beneficial because all of the useful water volume fraction of Lago Cerrillos is still available for use.

At the current long-term sedimentation rate and estimated sediment trapping efficiency, the life expectancy of Lago Cerrillos is not a pressing concern because the reservoir is estimated to not be completely filled with sediment until the year 2822 .

\section{References Cited}

Brune, G.M., 1953, Trap efficiency of reservoirs: Transactions of the American Geophysical Union, v. 34, no. 3, p. 407-418.

Environmental Systems Research Institute, Inc., 1992, Surface modeling with TIN, Surface analysis and display: Redlands, CA, Environmental Systems Research Institute, Inc., p. 4-1, 6-1.

Figueroa-Alamo, Carlos, and others, 2007, Water resources data Puerto Rico and the U.S. Virgin Islands, Water Year 2006: U.S. Geological Survey Water-Data Report PR-03$1,567 \mathrm{p}$.

Gaztambide-Vega, F., and Arán, Pedro P., 1959, La Isla de Puerto Rico: Chicago, IL, Rand McNally \& Co., p. 38-86.

Gierbolini, Roberto, 1979, Soil Survey of the Ponce Area of Southern Puerto Rico: U.S. Department of Agrculture, Soil Conservation Service, p. 3-4.

Heinemann, H.G., 1981, New sediment trap efficiency curve for small reservoirs: Water Resources Bulletin, v. 7, p. $825-830$.

McManus, J., and Duck, R.W., eds., 1993, Geomorphology and sedimentology of lakes and reservoirs: Reservoir sedimentation rates in the Southern Pennine Region, UK, chap. 6: New York, John Wiley \& Sons, p. 73-92.

U. S. Army Corps of Engineer, 1997, Portugues and Bucaná Rivers Puerto Rico, Water Control manual for Cerrillos dam and Reservoir, 9 Sections, accessed September 21,2009 , at

http://www.saj.usace.army.mil/h2o/lib/documents/ cerrillos/wcm-crrn.htm.

Verstraeten, G., and Poesen, J., 2000, Estimated trap efficiency of small reservoirs and ponds: methods and implications for the assessment of sediment yd: Progress in Physical Geography, v. 24, no. 2, p. 219-251. 


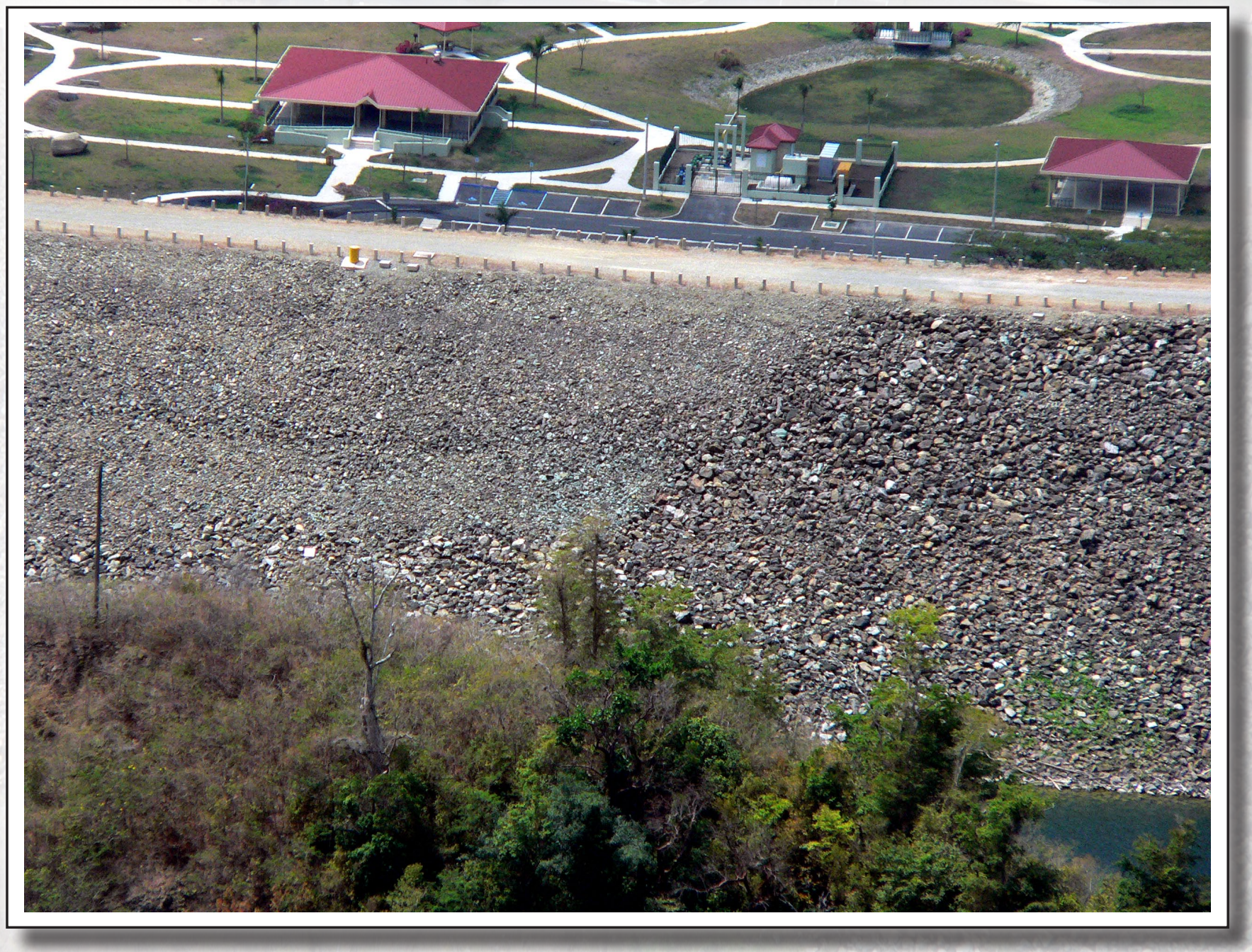

Aerial photograph of the Luis Antonio "Wito" Morales Park downstream of the Lago Cerrillos dam, Ponce, Puerto Rico. Photograph courtesy of the Puerto Rico Electric Power Authority, taken on May 9, 2006. 


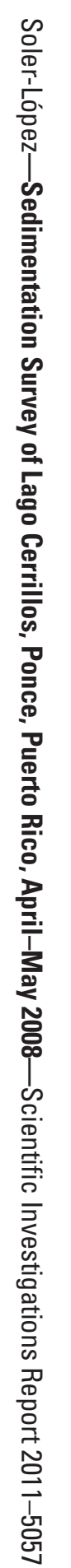

8 Printed on recycled paper 